\title{
Profil dermatitis kontak alergi di poliklinik rsup prof. Dr. R.D. Kandou Manado periode Januari - Desember 2013
}

\author{
${ }^{1}$ Timothy Batasina \\ ${ }^{2}$ Herry Pandaleke \\ ${ }^{2}$ Pieter Suling
}

\author{
${ }^{1}$ Kandidat Skripsi Fakultas Kedokteran Universitas Sam Ratulangi Manado \\ ${ }^{2}$ Bagian Ilmu Kulit dan Kelamin Fakultas Kedokteran Universitas Sam Ratulangi Manado \\ Email: tbatasina@gmail.com
}

\begin{abstract}
Allergic contact dermatitis is a delayed type hypersensitivity reaction (type IV) cell-mediated, as a result of specific antigens that penetrate the epidermal layer of the skin. In general, due to the chemicals contained in devices worn by patients such as accesories, clothing, shoes, cosmetics, and topical drugs or tools associated with the job. This study was aimed to determine the profile of allergic contact dermatitis in the department of Prof.Dr. RD Kandou Manado. This was a descriptive reprospective study. Subjects were patients who come to the Clinic of Skin and Venereolgyl Prof. Dr. R. D. Kandou Hospital Manado with the diagnosis of allergic contact dermatitis based on the data ofn medical records from January to December 2013. The most common patients were females (43\%) and aged 45-64 years (43\%). Most therapy consisted of antihistamin and corticosteroid (61\%).
\end{abstract}

Keywords: allergic contact dermatitis

\begin{abstract}
Abstrak: Dermatitis kontak alergi adalah reaksi hipersensitifitas tipe lambat (tipe IV) yang diperantai sel, akibat antigen spesifik yang menembus lapisan epidermis kulit. Pada umumnya disebabkan karena bahan kimia yang terkandung dalam alat-alat yang dikenakan oleh penderita seperti asesoris, pakaian, sepatu, kosmetika, dan obat-obatan topikal atau alatalat yang berhubungan dengan pekerjaan. Penelitian ini bertujuan untuk mengetahui profil dermatitis kontak laergi di RSUP Prof. Dr. R.D. Kandou Manado. Jenis penelitian ialah deskriptif retrospektif. Subjek penelitian ialah pasien yang datang ke Poliklinik Kulit dan Kelamin RSUP Prof. Dr. R. D. Kandou Manado dengan diagnosis dermatitis kontak alergi berdasarkan data di bagian rekan medik periode Januari sampai Desember 2013. Penderita yang paling sering terserang dermatitis ialah dewasa dengan usia 45-64 tahun (43\%), jenis kelamin perempuan $(66 \%)$. Jenis obat yang paling sering digunakan yaitu obat antihistamin serta kortikosteroid $(61 \%)$.
\end{abstract}

Kata kunci: dermatitis kontak alergi

Dermatitis kontak alergi (DKA) merupakan dermatitis yang terjadi akibat pajanan dengan bahan alergen dari luar tubuh. Dermatits kontak alergi ialah suatu peradangan kulit yang timbul setelah kontak dengan alergen melalui proses sensitisasi. Peradangan dan edema pada kulit diperantai olek reaksi imun tipe IV. ${ }^{1}$

Penyebab DKA pada umumnya adalah bahan kimia yang terkandung dalam alat- alat yang dikenakan oleh penderita (asesoris, pakaian, sepatu, kosmetika, obatobat topikal) atau yang berhubungan dengan pekerjaan (semen, sabun cuci, pestisida, bahan pelarut, bahan cat atau polutan yang lain). Disamping bahan penyebab, ada faktor penunjang yang mempermudah timbulnya dermatitis kontak tersebut yaitu suhu, udara, kelembaban, dan gesekan. ${ }^{1}$ 
Diperkirakan jumlah penderita dermatitis kontak alergi makin bertambah seiring dengan bertambahnya jumlah produk yang mengandung bahan kimia yang dipakai oleh masyarakat. ${ }^{1}$

Gejala klinis DKA pada umumnya gatal. Kelainan kulit bergantung pada tingkat keparahan dan lokasi dermatitisnya. Pada stadium akut didapatkan bercak eritematosa, edema, papul vesikel, bula, erosi, eksudasi. ${ }^{1}$ Pada dermatitis kontak alergi kronis terlihat kulit kering, berskuama, papul, likenifikasi, dan mungkin juga fisur, berbatas tidak tegas. Dermatitis kontak alergi dapat meluas ke tempat lain,misalnya dengan cara autosensitisasi. Berbagai lokasi kejadian dermatitis kontak alergi yaitu tangan, lengan, wajah, telinga, leher, badan, genitalia, tungkai atas dan bawah. ${ }^{1}$

Untuk mendiagnosis dermatitis kontak alergi didasari dengan hasil anamnesis yang cermat dan pemeriksaan klinis yang teliti. ${ }^{2}$ Pemeriksaan fisik sangat penting, karena dengan melihat lokasi dan pola kelainan kulit sering kali dapat diketahui kemungkinan penyebabnya. ${ }^{1}$ Pemeriksaan hendaknya dilakukan di tempat yang cukup terang, pada seluruh permukaan kulit untuk melihat kemungkinan kelainan kulit lain karena berbagai sebab endogen. Diagnosis banding dari dermatitis kontak alergi adalah dermatitis kontak iritan, dermatitis atopik, dermatitis numularis. ${ }^{2}$

Di Eropa pada tahun 2008, insiden penyakit ini cukup tinggi di Swedia ditemukan pada $4,8 \%$ dari populasinya. ${ }^{3}$ Di RS Dr. Pirngadi Medan pada tahun 2012, Nasution melaporkan terdapat 301 pasien dermatitis kontak alergi. Di Manado pada tahun 2012. Sunaryo melaporkan dari total penderita penyakit kulit berjumlah 4096, penderita dengan dermatitis kontak alergi sebanyak 77 orang $(7,02 \%)$

Berdasarkan uraian diatas, penulis tertarik melakukan penelitian untuk mengetahui profil pasien dermatitis kontak alergi di poliklinik kulit dan kelamin RSUP Prof. Dr. R. D. Kandou Manado periode Januari sampai Desember 2013.
Jenis penelitian ini ialah deskriptif retrospektif. Penelitian dilakukan di Poliklinik Kulit dan Kelamin RSUP Prof. Dr. R.D. Kandou Manado. Data diambil dari data rekam medis pasien Poliklinik Kulit dan Kelamin periode Januari sampai Desember 2013, dengan subjek penelitian ialah semua pasien dengan diagnosa Dermatitis Kontak Alergi. Data yang dikumpulkan meliputi usia, jenis kelamin, pekerjaan, lokasi, kemungkinan penyebab, terapi. Data diolah dengan program Microsoft Excel.

\section{HASIL PENELITIAN}

Berdasarkan penelitian yang sudah dilakukan, diperoleh yaitu 41 sampel. Tabel 1 menunjukkan yaitu Distribusi pasien dermatitis kontak alergi berdasarkan jumlah penderita di Poliklinik Kulit dan Kelamin RSUP Prof. Dr. R.D. Kandou Manado periode Januari-Desember 2013 didapatkan jumlah penyakit DKA 41 pasien (1\%) dan 4.058 pasien (99\%) merupakan penyakit kulit lainnya.

Tabel 1. Distribusi pasien dermatitis kontak alergi berdasarkan jumlah

\begin{tabular}{lcc}
\hline Penyakit & Jumlah pasien & (\%) \\
\hline $\begin{array}{l}\text { Dermatitis kontak } \\
\text { alergi }\end{array}$ & 41 & 1 \\
Penyakit kulit lain & 4.058 & 99 \\
Total & 4.099 & 100 \\
\hline
\end{tabular}

Tabel 2 memperlihatkan yaitu distribusi pasien dermatitis kontak alergi berdasarkan jenis kelamin di Poliklinik Kulit dan Kelamin RSUP Prof. Dr. R.D. Kandou Manado periode Januari-Desember 2013 didapatkan jumlah pasien perempuan lebih banyak daripada pasien laki-laki. Jumlah pasien perempuan sebanyak 27 pasien (66\%),sedangkan jumlah pasien laki-laki 14 pasien (34\%).

Tabel 3 memperlihatkan distribusi pasien dermatitis kontak alergi berdasarkan jenis kelamin di Poliklinik Kulit dan Kelamin RSUP Prof. Dr. R. D. Kandou Manado periode Januari-Desember 2013 didapatkan jumlah terbanyak pada usia 4564 tahun (43\%) diikuti golongan usia 25-44 
tahun $(24 \%)$.

Tabel 2. Distribusi pasien dermatitis kontak alergi berdasarkan jenis kelamin

\begin{tabular}{lcc}
\hline Jenis kelamin & N & \% \\
\hline Laki-laki & 14 & 34 \\
Perempuan & 27 & 66 \\
Total & 41 & 100 \\
\hline
\end{tabular}

Tabel 3. Distribusi pasien dermatitis kontak alergi berdasarkan usia

\begin{tabular}{ccc}
\hline Usia (tahun) & n & \% \\
\hline$<1$ & - & - \\
$1-4$ & - & - \\
$5-14$ & 3 & 8 \\
$15-24$ & 3 & 8 \\
$25-44$ & 10 & 24 \\
$45-64$ & 18 & 43 \\
$>65$ & 7 & 17 \\
Total & 41 & 100 \\
\hline
\end{tabular}

Tabel 4 memperlihatkan distribusi penderita dermatitis kontak alergi berdasarkan. Didapatkan pekerjaan terbanyak ialah IRT (Ibu Rumah Tangga) diikuti oleh pekerjaan PNS.

Tabel 4. Distribusi pasien dermatitis kontak alergi berdasarkan pekerjaan

\begin{tabular}{lcc}
\hline Pekerjaan & n & $(\boldsymbol{\%})$ \\
\hline Buruh bangunan & 2 & 5 \\
Pekerja salon & 1 & 3 \\
Ibu Rumah Tangga & 14 & 34 \\
Pembantu Rumah Tangga & - & - \\
Petani & 5 & 12 \\
Tukang ojek & 1 & 3 \\
Wiraswasta & 1 & 3 \\
Nelayan & - & - \\
Pelajar & 6 & 8 \\
Penjahit & - & - \\
PNS & 13 & 32 \\
Total & 41 & 100 \\
\hline
\end{tabular}

Tabel 5 memperlihatkan distribusi penderita dermatitis kontak alergi berdasarkan lokasi di poliklinik Kulit dan Kelamin RSUP Prof. Dr. R. D. Kandou Manado. Didapatkan area yang tersering terkena dermatitis kontak alergi ialah badan $(29,2 \%)$.

Tabel 5. Distribusi penderita dermatitis kontak alergi berdasarkan lokasi/area

\begin{tabular}{lcc}
\hline Lokasi/area & n & $(\mathbf{\% )}$ \\
\hline Tangan & 6 & 15 \\
Lengan & 2 & 5 \\
Kepala & 5 & 12,1 \\
Telinga & - & - \\
Leher & 3 & 8 \\
Badan & 12 & 29,2 \\
Genitalia & 1 & 2,4 \\
Paha \& tungkai bawah & 1 & 2,4 \\
Kaki & 11 & 27 \\
Total & 41 & 100 \\
\hline
\end{tabular}

Tabel 6 memperlihatkan distribusi pasien dermatitis kontak alergi berdasarkan penyebab di poliklinik Kulit dan Kelamin RSUP Prof. Dr. R. D. Kandou Manado didapatkan yang terbanyak adalah bahan kimia $(48,8 \%)$. Diikuti oleh penyebab lainnya seperti obat dan makanan.

Tabel 6. Distribusi pasien dermatitis kontak alergi berdasarkan penyebab

\begin{tabular}{lcc}
\hline Kemungkinan penyebab & n & \% \\
\hline Karet & 4 & $9,8 \%$ \\
Bahan kimia & 20 & 48,8 \\
Lainnya (obat,makanan,dll) & 17 & $41,4 \%$ \\
Total & 41 & $100 \%$ \\
\hline
\end{tabular}

Tabel 7 memperlihatkan distribusi jenis obat yang paling sering digunakan pasien dermatitis kontak alergi di poliklinik Kulit dan Kelamin RSUP Prof.Dr. R.D. Kandou Manado didapatkan yang sering digunakan terapi obat antihistamin + kortikosteroid sebanyak $25 \%$, diikuti oleh terapi obat antihisatmin $10 \%$.

Tabel 7. Distribusi pasien dermatitis kontak alergi berdasarkan jenis obat yang dipakai

\begin{tabular}{lcc}
\hline Jenis obat & n & $\mathbf{( \% ) ~}$ \\
\hline Anti histamin & 10 & $24 \%$ \\
Kortikosteroid & 6 & $15 \%$ \\
$\begin{array}{l}\text { Antihistamin + } \\
\text { kortikosteroid }\end{array}$ & 25 & $61 \%$ \\
\hline Total & 41 & $100 \%$ \\
\hline
\end{tabular}

\section{BAHASAN}

Pada Tabel 1 menunjukan distribusi pasien di poliklinik kulit dan kelamin RSUD Prof. Dr. R.D. Kandou Manado 
pada tahun 2013 didapatkan $41(1 \%)$ kasus dermatitis kontak alergi dan 4.058 pasien lainya menderita penyakit kulit yang lain. Terjadi penurunan dibandingkan dengan jumlah pasien yang berkunjung ke poliklinik kulit dan kelamin RSUD Prof. Dr. R.D. Kandou Manado berjumlah 77 pasien $(7,02 \%)$ dari 4.023 pada tahun 2012 . Hal ini dapat terjadi oleh karena masyarakat sudah mengetahui kemungkinan penyebab atau faktor pencetus sehingga dapat menghindari penyakit ini.

Pada Tabel 2 distribusi pasien dermatitis kontak alergi berdasarkan jenis kelamin di Poliklinik RSUP PROF R.D. Kandou Manado periode Januari-Desember 2013, bahwa jenis kelamin perempuan 27 pasien (66\%) lebih banyak terkena dermatitis kontak dari pada laki-laki 14 pasien $(34 \%)$. Penyebab hal ini terjadi oleh karena beberapa faktor seperti pekerjaan ataupun produk yang mengandung bahan kimia contohnya deterjen, alat kosmetik dan sabun cuci piring, yang sering terkena kontak langsung dengan perempuan. Hasil Penelitian yang didapatkan ini terjadi seperti pada tahun 2003 di RS Dr. Pirngadi Medan, Nasution melaporkan terdapat 301 pasien dermatitis kontak (laki-laki 109 orang dan wanita 192 orang), Pada umumnya pasien perempuan lebih banyak terkena DKA. Prevalensi pada wanita dua kali lipat dari pada lakilaki. ${ }^{5}$ Hal ini kemungkinan karena wanita di usia ini merupakan usia kerja dan usia pelajar / mahasiswa, yang banyak memakai asesoris, kosmetik, parfum, dan bahan kimia lainnya.

Pada Tabel 3 yang paling banyak terkena dermatitis kontak alergi adalah orang dewasa pada umur 45-64 tahun sebanyak 18 orang (43\%), diikuti oleh orang dewasa usia 25-44 tahun sebanyak 10 orang (24\%) dapat dilihat pada tabel 3. Hal ini bisa disebabkan oleh karena penurunan daya tahan tubuh pada usia ini sedangkan pada usia tersebut masih banyak pekerjaan yang berpaparan langsung dengan alergen. Akan tetapi usia tidak mempengaruhi timbulnya sensitisasi namun dermatitis kontak alergik lebih sering timbul pada usia dewasa tapi dapat mengenai segala usia. ${ }^{5}$

Pada Tabel 4 pekerjaan terbanyak merupakan Ibu Rumah Tangga sebanyak 14 pasien dan yang paling sedikit merupakan pekerja salon,tukang ojek,wiraswasta sebanyak 1 pasien (3\%). Ibu rumah tangga menjadi yang paling banyak terkena penyakit dermatitis kontak alergi, kemungkinan faktor lingkungan dan pekerjaan. Hal ini berhubungan dengan kegiatan sehari-hari seorang ibu rumah tangga yang selalu berhubungan dengan dapur maupun deterjen. Hal ini terbukti dengan keluhan dari beberapa kasus pasien yang datang Poliklinik RSUP Prof. R.D. Kandou Manado periode Januari-Desember 2013 dan data rekam medik RSUP Prof. R.D. Kandou Manado periode JanuariDesember 2013.

Pada Tabel 5 menunjukan lokasi yang paling sering adalah bagian badan sebanyak 12 orang, diikuti oleh kaki sebanyak 11 pasien. Bagian badan dan kaki menjadi bagian yang tersering terkena dermatitis kontak alergi oleh karena terkena paparan langsung dengan bahan karet. ${ }^{6}$ Dalam hal ini pasien yang datang di Poliklinik RSUP Prof. R.D. Kandou Manado periode Januari-Desember 2013 dan hasil data rekam medik RSUP Prof. R.D. Kandou Manado periode Januari-Desember 2013, didapatkan pasien mengeluh merasakan gatal di area badan oleh karena pemakaian pada sabun saat mandi. Adapun pasien yang datang dengan keluhan merasakan gatal di bagian kaki setelah memakai sendal yang berbahan dasar karet.

Pada Tabel 6 menunjukan penyebab tersering adalahbahan kimia sebanyak 20 pasien $(48,8 \%)$. Hal ini kemungkinan terjadi karena bahankimia yang terkandung dalam alat-alat yang dikenakan oleh penderita sepertiperhiasan, pakaian, sepatu, sandal, kosmetika. Ada juga yang berhubungan dengan pekerjaan seperti semen, sabun cuci, bahan pelarut, bahan cat, deterjen dan lainnya. Diperkirakan jumlah penderita dermatitis kontak alergi makin bertambah seiring dengan 
bertambahnya jumlah produk yang mengandung bahan kimia yang dipakai oleh masyarakat. ${ }^{1}$

Pada Tabel 7 jenis obat yang paling sering digunakan untuk pasien yang terdiagnosis Dermatitis Kontak Alergiialah terapi obat antihitamin + kortikosteroid. Pengobatan antihistamin ditujukan untuk mengontrol rasa gatal danatau edema, juga pada kasus-kasus sedang dan berat pada keadaan akut ataukronik. Maksud pemberian antihistamin adalah untuk memperoleh efek sedatifnya dan kortikosteroid diberikan pada kasus yang sedang atau berat, secara peroral,intramuskular atau intravena. Bila diberikan dalam waktu singkat maka efek sampingnya akan minimal. Perlu perhatian khusus pada penderita ulkuspeptikum, diabetes dan hipertensi. Efek sampingnya terutama pertambahan berat badan, gangguan gastrointestinal dan perubahan dari insomnia hingga depresi. ${ }^{1,7,8}$ Kortikosteroid mempunyai peranan penting dalam sistem imun. Pemberian topikal akan menghambat reaksi aferen dan eferen daridermatitis kontak alergik. ${ }^{1,4,9}$ Untuk DKA yang akut diberikan kortikosteroid dalam jangka waktu pendek untuk mengatasi peradangan. ${ }^{10}$ Apabila gejala mereda diganti dengan kortikosteroid topical.

\section{SIMPULAN}

Dari hasil penelitian retrospektif yang dilakukan selama periode JanuariDesember 2013 di Poliklinik Kulit dan Kelamin RSUP Prof. Dr. R.D. Kandou Manado dapat disimpukan, jumlah penderita dermatitis kontak alergi selama periode Januari-Desember 2013 di Poliklinik Kulit dan Kelamin RSUP Prof. Dr. R. D. Kandou Manado sebanyak 41 pasien. Kelompok paling banyak terkena dermatitis kontak alergi adalah orang dewasa pada umur 45-64 tahun sebanyak 18 orang $(43 \%)$. Jenis kelamin yang terbanyak pada penderita dermatitis kontak alergi adalah perempuan sebanyak 27 pasien $(66 \%)$. Pekerjaan terbanyak pada penderita dermatitis kontak alergi adalah
Ibu Rumah Tangga (IRT) 14 pasien (34\%). Lokasi yang terseringpada penderita dermatitis kontak alergiadalahbadan sebanyak 12 pasien $(29,2 \%)$. Penyebab tersering pada penderita dermatitis kontak alergi adalah bahan kimia sebanyak 20 pasien $(48,8 \%)$. Jenis obat/terapi yang paling sering digunakan pada pasien dermatitis kontak alergi adalah terapi obat antihitamin + kortikosteroid 25 pasien (61\%). Jumlah penderita penyakit DKA pada tahun 2013 mengalami penurunan dibandingkan tahun 2012.

Data mengenai DKA di Indonesia terlebih khusus di Manado masih kurang sehingga perlu diadakan penelitian lebih lanjut dan sebaiknya berkala untuk pemantauan yang lebih baik. Kelengkapan dalam pengisian status pasien sangat diperlukan guna menunjang pendekatan yang lengkap,akurat,dan informatif untuk penelitian selanjutnya.

\section{DAFTAR PUSTAKA}

1. Fitspatrick's dermatology in general medicine vol.1\& 2 (7th ed). 2008. $\mathrm{p}: 130-35$

2. Sularsito SA, Menaldi S. In: Buku ajar Ilmu Penyakit Kulit dan Kelamin (7th ed). Jakarta: FKUI, 2015; p: 161-6.

3. Beltrani V. Contact dermatitis: A practice parameter. Ann Allergy Asthma Immunol. 2006;(1):1-38.

4. Bogle MA, Militello G. Contact dermatitis. In: Ali A, editor. Dermatology: pictorial review (2nd ed). USA, 2010; p. 81-93.

5. Sunaryo Y. Profil Dermatitis kontak di poliklinik Kulit dan Kelamin BLU RSUP Prof. Dr. R. D. Kandou Manado periode Januari - Desember 2013 (Skripsi). Manado: FK Unsrat; 2014.

6. Debson RL, Abele DL. In The practice of dermatology. Philadelphia: Harper and Row, 2005; p.121-30.

7. Djuanda A. Ilmu penyakit kulit dan kelamin (6th ed). Jakarta: FKUI, 2010; p. 129-38.

8. Sanja, Maaike J, Maarten M. Individual Suscepibility to Contact Dermatitis. Industrial Health. 2009;47:469-78.

9. Trihapsoro. Dermatitis. In: Ilmu penyakit 
Batasina, Pandaleke, Suling: Profil dermatitis kontak...

kulit dan kelamin. Jakarta: FKUI, and occupational dermatology (3rd 2003; p.121-9.

10.Mark JG, Elsner P, Deleo V. In: Contact ed). St. Louis: Mosby, 2005; p. 3-15. 